\title{
OBSERVATIONS ON THE INHERITANCE OF SICKLE-CELL HEMOGLOBIN AND HEMOGLOBIN $\mathrm{C}^{1}$
}

\author{
By HELEN M. RANNEY \\ (From the Department of Medicine, College of Physicians and Surgeons, Columbia University, \\ and the Presbyterian Hospital in the City of New York)
}

(Submitted for publication June 17, 1954 ; accepted August 13, 1954)

The recognition of hemoglobin $\mathrm{C}(1,2)$ an hereditary abnormality of hemoglobin, occurring in Negroes, has been important for the clinical and genetic concepts of the hereditary hemolytic anemias. The presence of hemoglobin $C$ appears to depend upon a single gene which is transmitted as a simple Mendelian dominant (2-4). The presence of sickle-cell hemoglobin is similarly determined by a single autosomal dominant gene. While the clinical syndrome accompanying the simultaneous presence of sickle and $C$ hemoglobin has been described, the precise relationships between the genes for hemoglobin $\mathrm{C}$ and sickle hemoglobin have not yet been elucidated. The possibilities are: 1) That the genes for sickle-cell and hemoglobin $\mathrm{C}$ are inherited independently and that the clinical syndrome results from the interaction of non-allelic genes; 2) that the genes for sickle-cell hemoglobin and hemoglobin $\mathrm{C}$ are alleles or are closely linked upon the same chromosome. To distinguish between allelism and close linkage would require a very large series. However, by studying the offspring of marriages of sickle-cell-hemoglobin $\mathrm{C}$ disease $\times$ normal, some conclusions as to independence $v s$. allelism or close linkage may be reached. The present report includes seven families in which both sicklecell hemoglobin and hemoglobin $\mathrm{C}$ have been found, in addition to three similar families which were reported previously (4). The number of observations is now large enough to permit some conclusions about the relationships of the genes for $\mathrm{C}$ and $\mathrm{S}$ hemoglobins.

Two additional cases of hemoglobin $C$ disease (homozygosity for the gene for hemoglobin C) are presented. The clinical features of the cases of sickle-cell-hemoglobin $\mathrm{C}$ disease in this study are similar to those previously reported $(2-6)$. The

\footnotetext{
1 This research has been partially supported by a gift of the Blood Transfusion Association.
}

case histories are presented primarily to provide a documentary basis for the genetic considerations.

\section{METHODS}

Hemoglobin $\mathrm{C}$ and sickle hemoglobin were identified by filter paper electrophoresis (7). Each specimen containing hemoglobin $\mathrm{C}$ was placed upon a filter paper containing four or five other samples of this abnormal hemoglobin. During a single run, all specimens of hemoglobin $C$ had the same mobility, thus eliminating the possibility of erroneous identification of hemoglobin $\mathrm{E}$ as hemoglobin C. Some of the papers of family studies are reproduced in the photographs in Figure 1. Alkali denaturation was carried out by an adaptation of the method of Lichtman and Watson, and Ponder and Levine $(8,9)$. Hemoglobin $C$ was crystallized by the method of Drabkin (10); its crystalline characteristics are identical with those of normal adult hemoglobin when examined under the ordinary microscope.

\section{CASE REPORTS}

\section{Hemoglobin $C$ disease}

I. D. C., a Negro insurance salesman, was born in British Guiana. He was first seen in the out-patient clinic in 1946 at the age of 44 for right lower quadrant pain, of uncertain etiology. There was a history of migratory polyarthritis accompanied by malaise at the age of 22 which had subsided after a few months. At age 34 , he had another episode of polyarthritis following gonorrheal urethritis. Physical examination in 1946 revealed a well-developed, well-nourished Negro male, who appeared to be in good health. There was slight cardiac enlargement, with a soft diastolic murmur along the left cardiac border. The blood pressure was 140/90. No enlargement of the liver or spleen was detected. Laboratory findings included hemoglobin of 13.0 grams per cent and ESR 3 millimeters in one hour (Westergren). Both the Kline and the Wassermann tests were strongly positive; no abnormalities were found in the spinal fluid. The patient received a course of penicillin and bismuth. He was next seen in 1950 for symptoms of a duodenal ulcer which was demonstrated on gastrointestinal x-rays. In 1952, he was admitted to the hospital for gastrointestinal bleeding. At that time, the spleen was palpable 2 to $3 \mathrm{~cm}$. below the left costal margin. The aortic diastolic murmur was apparently un- 
changed from previous description. Laboratory findings included hemoglobin 9.7 grams per cent, stool guaiac test was strongly positive. Many target cells were noted on stained smears, and a sickling preparation was negative. The bleeding subsided promptly and the patient was discharged from the hospital. In 1953, he was readmitted for repair of an inguinal hernia. The splenomegaly was still present; the diastolic cardiac murmur was not heard by some observers. Laboratory findings at this time were : Hemoglobin 13.5 grams per cent, WBC 5,300 per cu. mm., with a normal differential count. Reticulocytes were 1.6 per cent, platelets 144,000 per cu. mm. The blood smear showed nearly 100 per cent target cells. Bone marrow aspiration revealed erythroid hyperplasia; 62 per cent of the nucleated cells were of the erythroid series. Mechanical fragility was 3 per cent (normal less than 5 per cent). Osmotic fragility: hemolysis began at 0.40 , incomplete at 0.20 for patient's erythrocytes with range of 0.45 to 0.30 per cent saline for normal control. Four weeks following the uneventful herniorraphy he was seen in clinic where the hemoglobin was 13.6 grams per cent. Erythrocytes were 4.4 million per cu.mm. with 1.9 per cent reticulocytes. Hematocrit was 37 per cent.

Filter paper electrophoresis showed that all the hemoglobin was of the $\mathrm{C}$ variety. His wife was found to have normal hemoglobin, and their only son had hemoglobin $\mathrm{C}$ trait, the combination of $\mathrm{C}$ and normal hemoglobin (Figure 2, group II).

II. Ja. T., a three and one-half-year-old Negro child, was seen as a member of family J. G. (Figure 2, group IV). His mother (V. T.) had been told that she was anemic and was found to have sickle-cell-hemoglobin $\mathrm{C}$ disease. His father (Jo. T.) had always been well; blood smears taken during this study showed an increased number of target cells and the filter paper electrophoresis of the father's hemoglobin showed the combination of $\mathrm{C}$ and normal hemoglobin. The son, Ja. T., was said to have been jaundiced at birth, with persistence of jaundice for 2 to 3 months thereafter. The child had been slow in development, and at age three and one-half years could not stand alone or talk, although he could apparently hear normally. At the time these studies were done he was hospitalized at a rehabilitation hospital with a diagnosis of cerebral palsy of the choreoathetotic type. Physical examination revealed retardation in development; there was no jaundice and the spleen was not felt.

The laboratory findings included: Hemoglobin 12 grams per cent, erythrocytes 4.5 million per cu. $\mathrm{mm}$.; hematocrit was 40 per cent with reticulocytes 1.2 per cent. The leucocyte count was 8,100 per cu. mm., neutrophils 26, lymphocytes 72 , monocytes 2 . Target cells comprised over 85 per cent of the erythrocytes.

Filter paper electrophoresis revealed an unusual pattern (see Figure 1): The major part of the hemoglobin was in the position of hemoglobin C. However, there was a small amount of another hemoglobin which on repeated and longer runs migrated between sickle and normal hemoglobin. This is the position of migration of fetal hemoglobin. Alkali denaturation showed 6 per cent alkali- resistant hemoglobin (values for normal hemoglobin by this method are below 3 per cent [8]). The faster component on the paper electrophoresis pattern, probably fetal hemoglobin, comprised 14 to 16 per cent of the total hemoglobin as determined by dye elution (6).

Family studies: Group I, Marriage of sickle-ccll trait individuals $\times$ hemoglobin $C$ trait individuals

Family R. L. (Figure 2, group I, c). R. L., Jr. was seen initially in 1947 at the age of 11 , for dyspnea of one year's duration. A febrile illness with vomiting, chest and abdominal pain during the preceding year had been diagnosed as rheumatic fever. He had cardiac enlargement by physical examination and by $\mathrm{x}$-ray with systolic and diastolic apical murmurs. The spleen was not felt. Laboratory findings were: Hemoglobin 8.2 grams per cent, erythrocytes, 3.7 million per cu. mm. Sickling tests were positive, with many target cells noted on smear. Electrocardiogram was within normal limits. Patient was followed during the next seven years in cardiac and hematology clinics. He developed a leg ulcer in 1951 which healed slowly. In 1952, he developed abdominal pain with signs of peritoneal irritation in the right lower quadrant; a normal appendix was removed. During recent years he has had no more abdominal pain; his hemoglobin has ranged between 10 and 12 grams per cent with 2 to 3 per cent reticulocytes and many target cells have always been found on stained smears. Whether he has rheumatic heart disease in addition to his hemolytic anemia has not been established.

Filter paper electrophoresis showed that his hemoglobin was a mixture of $\mathrm{C}$ and sickle hemoglobin. Additional members of the family were studied (Figure 1), one younger brother also had sickle-cell-hemoglobin $\mathrm{C}$ disease.

The brother (H. L.) was seen in the out-patient department in 1952 at the age of 8 , for frequent attacks of pharyngitis. Physical examination revealed the spleen to be palpable 3 to $4 \mathrm{~cm}$. below the left costal margin. The hemoglobin was 9.4 grams per cent, erythrocytes 3.7 million per cu. mm. Leucocytes and platelets were normal. Many target cells were noted on stained smears. The patient was seen subsequently in the clinic for an attack of abdominal pain, and on another occasion for pain in the forearm; both of these episodes subsided within a few days. The splenomegaly did not change appreciably during the two years of observation. Filter paper electrophoresis of the hemoglobin revealed the combination of sickle and $\mathrm{C}$ hemoglobin.

Of the other siblings, two have sickle-cell trait, three have hemoglobin $\mathrm{C}$ trait, and one died in the neonatal period. None of the offspring studied was normal.

Family A. B. (Figure 2, group I, a). A. B., an 11year-old Negro schoolgirl, was first seen in the Babies' Hospital in 1953 for pain in the left elbow of three days' duration. She had had recurrent attacks of polyarthritis since the age of six. Physical examination revealed tenderness, without swelling, of the right elbow. No cardiac abnormalities were noted. The spleen tip was 
palpable just below the left costal margin. Laboratory examinations showed: Hemoglobin, 9.9 grams per cent: erythrocytes, 3.9 million per $\mathrm{cu}$. $\mathrm{mm}$; hematocrit 33.7 per cent. Target cells were noted in descriptions of blood smears. ESR was $4 \mathrm{~mm}$. in one hour (Westergren). Serum bilirubin was 3.5 milligrams per cent. The pain subsided without significant decrease in hemoglobin and the patient was discharged from the hospital.

Filter paper electrophoresis showed her hemoglobin to consist of a mixture of sickle and $C$ hemoglobin. The hemoglobin of her sister showed the pattern of sickle-cell trait. The mother had hemoglobin $\mathrm{C}$ trait and the father sickle-cell trait.

Family J. G. (Figure 2, group I, d). J. G., the index case in this family, was admitted to an Air Force hospital for subacute bacterial endocarditis. There was a history of "aching" of the extremities at the age of six, which had been treated with several months of bed rest. One year prior to hospitalization the patient had been rejected as a blood donor because of anemia. Physical examination revealed a basal diastolic murmur, and the spleen was palpable 2 to $3 \mathrm{~cm}$. below the left costal margin. Labora- tory findings were: Hemoglobin 11.5 grams per cent, erythrocytes 4.9 million per cu. mm., hematocrit 34 per cent, reticulocytes 2.5 per cent. The leucocytes were normal. An increased number of target cells was noted on blood smears and sickling preparations were positive. Filter paper electrophoresis of the patient's hemoglobin revealed the characteristic pattern of sickle-cell-hemoglobin $\mathrm{C}$ disease.

The remainder of the family were studied: The father had sickle-cell trait, the mother, hemoglobin $\mathrm{C}$ trait. Of the five siblings tested (one was unavailable) three had a pattern identical with that of the patient; one was normal, and one had sickle-cell trait.

Clinical and hematological data on the three siblings in this family with sickle-cell-hemoglobin $\mathrm{C}$ disease were incomplete. However, V. T. had a history of anemia and arthralgias with a positive sickling preparation, and an increased number of target cells on stained blood smears. Her reticulocytes were 3.4 per cent. She was the mother of Ja. T. (hemoglobin C disease). One sister, Je. G., age 26 , had symptoms of weakness and arthralgias with a hemoglobin of 12 grams per cent, hematocrit of
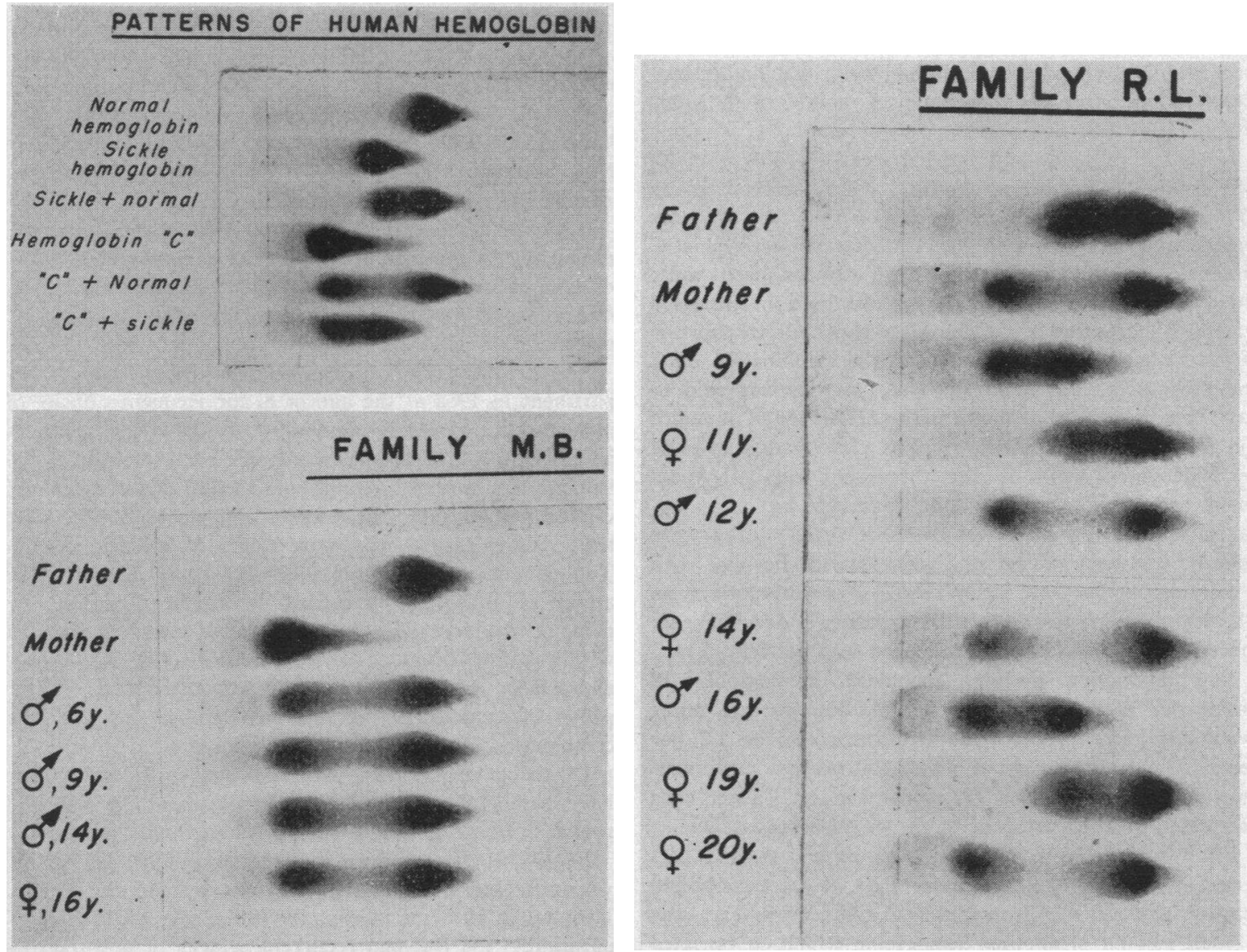

Fig. 1. Photographs of the Filter Paper Preparations of Selected Family Studies

The distortion of the hemoglobin pattern of the mother of Family C. W. is the result of prolonged storage of that hemoglobin specimen. 


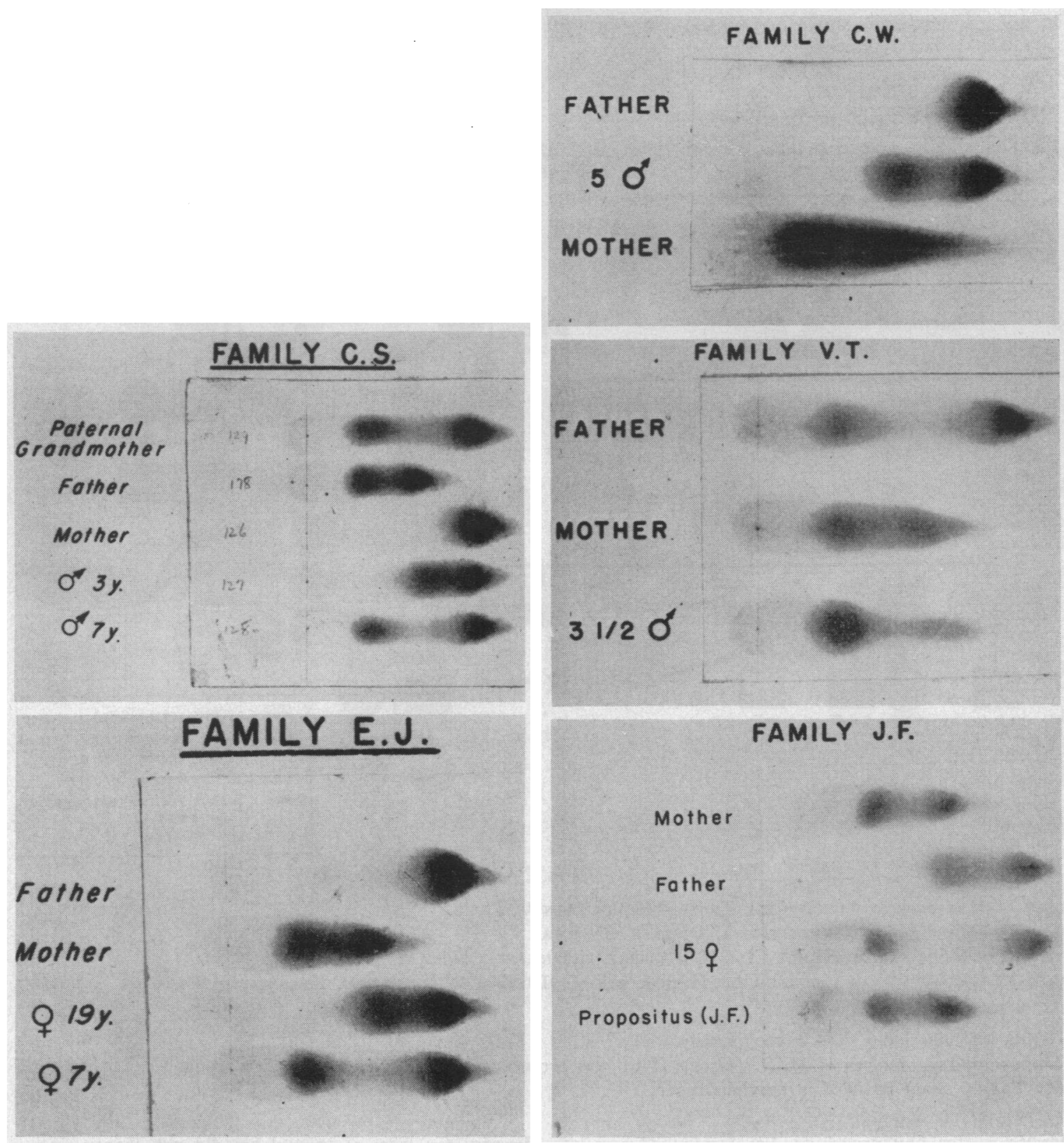

FIG. 1-Continued

36 per cent and about 30 per cent target cells on smears. Her brother, A. G., age 17 , was asymptomatic, but his spleen was palpable $3 \mathrm{~cm}$. below the left costal margin. His hemoglobin was 14 grams per cent, the hematocrit was 37 per cent and a blood smear showed 50 per cent target cells. Specimens of hemoglobin from these three siblings (V. T., Je. G., and A. G.) all showed a mixture of $\mathrm{C}$ and sickle hemoglobin.

Group II. Marriage of hemoglobin $C$ disease $\times$ normal

(Figure 2, group II, $a$ and $b$ ). M. B., homozygous for the gene for hemoglobin $C$, previously reported (4) and her husband whose hemoglobin was normal, had four children, all with hemoglobin $\mathrm{C}$ trait (Figure 1). D. C. (clinical history reported above) and his wife whose hemoglobin was normal have one son with hemoglobin C trait.

Group III. Marriage of sickle-cell-hemoglobin $C$ disease $\times$ normal

Family E. J. (Figure 2, group $I I I, c)$. E. S. J. was first seen in 1932 at the age of 22 during her second pregnancy. She had her initial attack of arthralgias and fever at the age of 12 , and had had several attacks 


\section{FAMILY STUDIES}
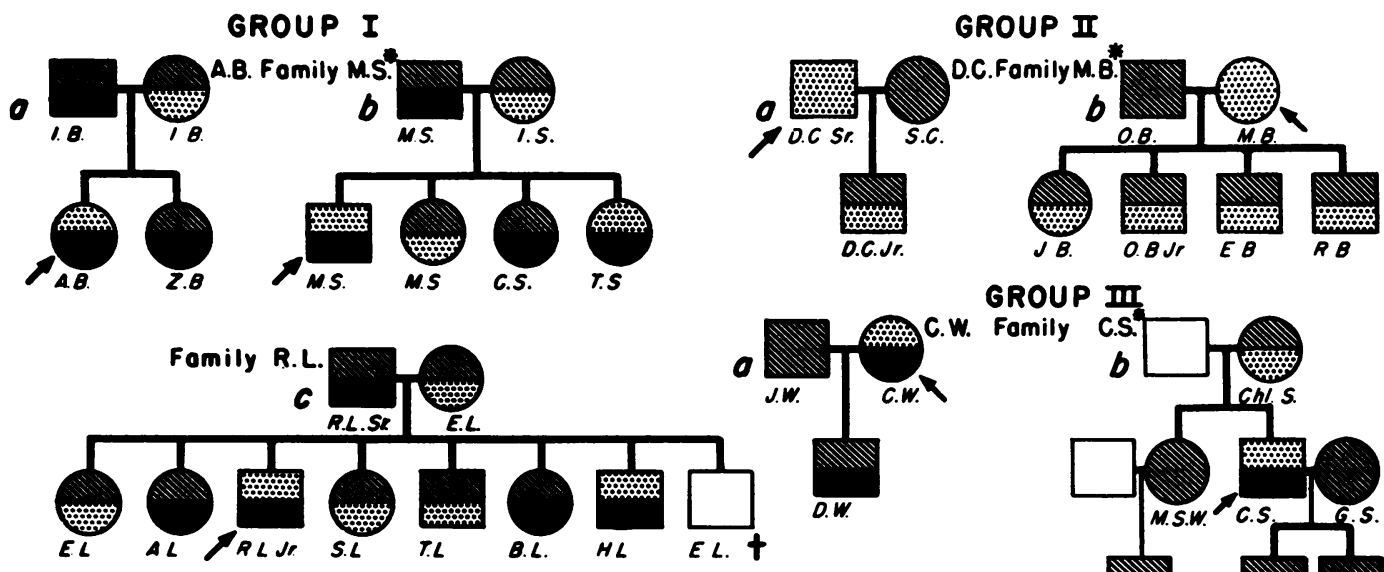

GROUP III
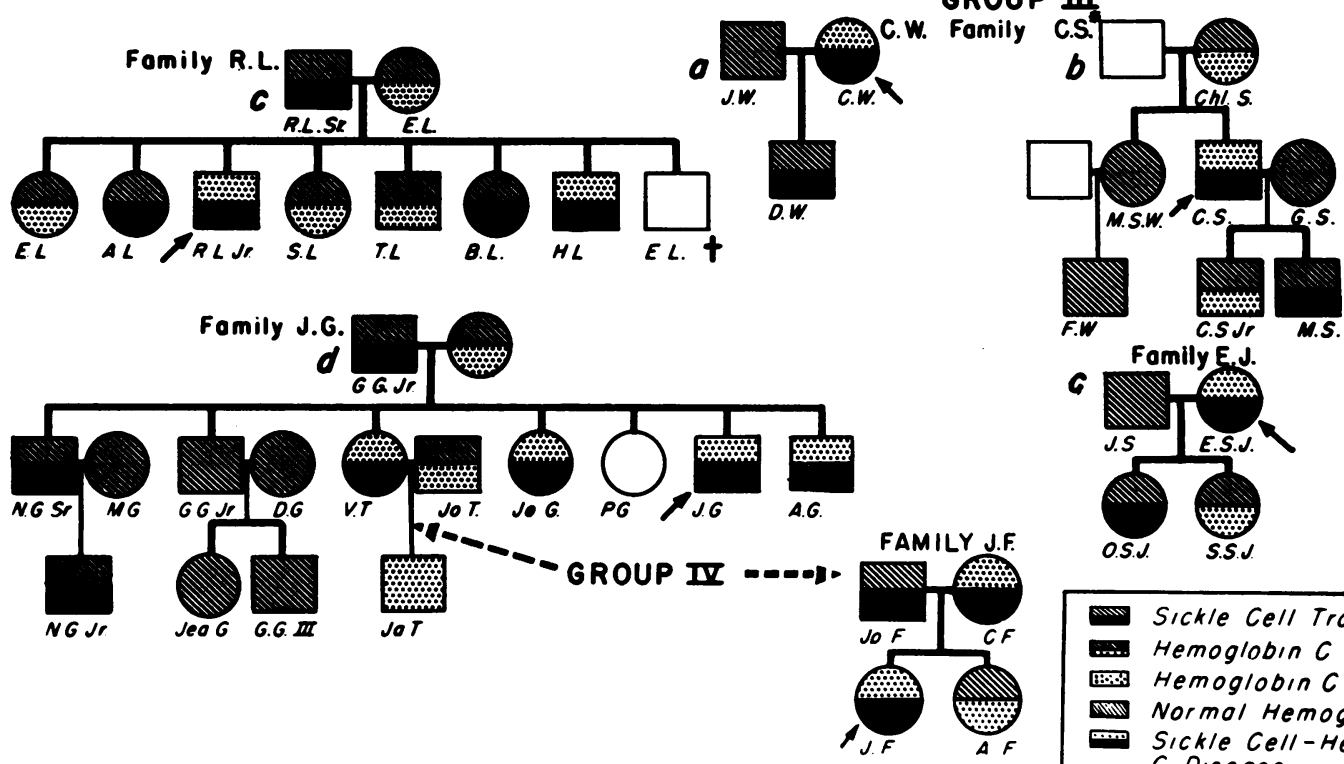

$\boldsymbol{c}$
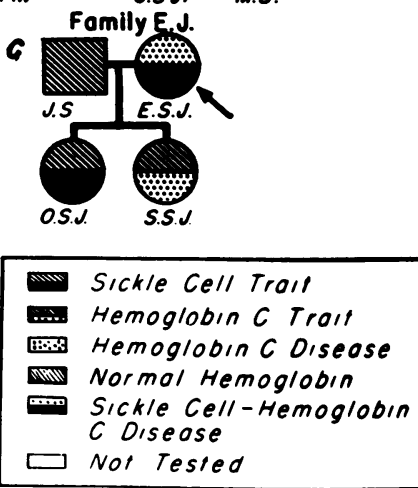

FIG. 2.

Group I-Marriage of Sickle-Cell Trait $\times$ Hemoglobin C Trait

Group II-Marriage of Hemoglobin C Disease $\times$ Normal

Group III-Marriage of Sickle-Cell-Hemoglobin C Disease $\times$ Normal

Group IV-Marriage of Sickle-Cell-Hemoglobin C Disease $\times$ Individual Heterozygous for an Abnormal HEMOGLOBIN

Arrow indicates index case in each family.

The sex of two children of M. B. (Group II b) was erroneous in the diagram in earlier report (4).

(*) Family study included in previous report (4).

thereafter. Her first pregnancy was terminated because of anemia and "heart trouble." In 1932, systolic and diastolic apical murmurs, mild cardiac enlargement, and a spleen palpable 3 to $4 \mathrm{~cm}$. below the left costal margin were noted. A sickling preparation was found to be positive, the hemoglobin was "75 per cent," erythrocytes 3.7 million per cu. $\mathrm{mm}$. with 14 per cent reticulocytes. The pregnancy was uneventful and a healthy child was delivered at term. Thereafter this patient was admitted to the hospital several times: in 1938 and in 1951, early therapeutic abortions were done and in 1944 a second normal pregnancy proceeded to term uneventfully. Two hospitalizations for pleuritic pain, without roentgenographic findings, may have been related to sickle-cell disease; the level of hemoglobin did not change during these admissions, however. For 22 years of observation the splenomegaly remained unchanged, as did the cardiac size and cardiac murmurs. The hemoglobin ranged from 10 to 13 grams per cent with reticulocytes varying between 4 and 14 per cent. Target cells were noted repeatedly on stained blood smears. The hemoglobin of the patient was found to consist of a mixture of sickle and $\mathrm{C}$ hemoglobins; the hemoglobin of her first husband J. S. (the father of both children) was normal. One child had sickle-cell trait; the other, hemoglobin $\mathrm{C}$ trait.

Family C.W. (Figure 2, group $I I I, a)$. The clinical findings of C. W., a 30-year-old Negro housewife with 
sickle-cell-hemoglobin C disease, were reported previously (4). Hemoglobin studies were subsequently carried out on the husband and son of C. W. The hemoglobin of her husband proved to be normal; their only son had the combination of sickle and normal hemoglobin.

Family C. S. (Figure 2, group $I I I, b)$. This family consisting of a father with sickle-cell-hemoglobin $\mathrm{C}$ disease has been reported previously (4). The hemoglobin of his wife was normal; one son had sickle-cell trait, and the other hemoglobin $\mathrm{C}$ trait.

Group IV. Marriage of sickle-cell-hemoglobin $C$ disease $\times$ the heterozygous state for an abnormal hemoglobin

A. Sickle-cell hemoglobin $C$ disease $\times$ sickle cell trait.

Family J. F. (Figure 2, group IV). J. F., a Negro schoolgirl, had her first symptoms at age 10 when she was hospitalized for fever and pains in the extremities. A diagnosis of poliomyelitis was made, but no residual deformities occurred. A similar attack occurred one year later, again without sequelae. At the age of 13 she was admitted to the Presbyterian Hospital for right lower quadrant pain and vomiting. The hemoglobin was 12.4 grams per cent, latent sickling was noted in a wet preparation. The leucocyte count was 16,100 per cu. mm. with 92 per cent neutrophils. A normal appendix was removed. The patient had no further symptoms until the age of 17 , when she had an episode of right arm pain which subsided after a few days. Hemoglobin was then 10.3 grams per cent, erythrocytes were 3 million per cu. mm. Reticulocytes were 2.9 per cent with rare nucleated red blood cells and many target cells on peripheral blood smears. Filter paper electrophoresis revealed her hemoglobin to be a mixture of sickle and $\mathrm{C}$ hemoglobin. The hemoglobin of her sister was shown to be that of hemoglobin $\mathrm{C}$ trait (Figure 1). The hemoglobin of her mother was found to be identical, by filter paper electrophoresis, with that of the patient. After some delay, a hemoglobin specimen was obtained from the father; he was shown to have sickle-cell trait. Blood grouping studies (including $\mathrm{ABO}, \mathrm{MN}, \mathrm{Rh}, \mathrm{Kell}$, and Duffy) were carried out on the members of this family; no evidence of non-paternity was found.

C. W. F., the mother, was 37 years of age. She had a history of anemia with pregnancies, and an episode of unexplained hematuria at the age of 28 . At the time of the study, her spleen was palpable 3 to $4 \mathrm{~cm}$. below the left costal margin. Her hemoglobin was 12.5 grams per cent, erythrocytes were 4.5 million per cu. $\mathrm{mm}$. Leucocytes were 4,600 per cu. $\mathrm{mm}$. and reticulocytes were 2.4 per cent.

B. Marriage of sickle-cell-hemoglobin $C$ disease $\times$ hemoglobin $C$ trait

(Figure 2, group IV). This marriage (of V. T. and Jo. T.) was encountered in Family J. G. The only son had hemoglobin $\mathrm{C}$ disease.

\section{RESULTS}

The data from this and previous study (4) are summarized in Table I. Photographs of the filter paper electrophoresis study of one family in each of groups I and II, and of each family study in groups III and IV are shown in Figure 1.

\section{DISCUSSION}

The data from groups I, II, III, and IV indicate that the genes for $\mathrm{C}$ and sickle hemoglobin probably segregate as simple Mendelian dominants. It is noteworthy that an unexpectedly small number of normal offspring of marriage $\mathrm{C} /+\times \mathrm{S} /+$ were found. Even if the four index cases $(C / S)$ are excluded, there is still an apparent deficiency of offspring with normal hemoglobin. The total number of children is, however, too small to permit reliable statistical evaluation, and furthermore this has not been noted in a series observed by

TABLE I

\begin{tabular}{|c|c|c|c|c|c|c|c|}
\hline . & \multirow{2}{*}{$\begin{array}{c}\text { Total } \\
\text { marriages }\end{array}$} & \multicolumn{5}{|c|}{ Number of offspring } & \multirow{2}{*}{$\begin{array}{l}\text { Total } \\
\text { offspring }\end{array}$} \\
\hline & & $\mathbf{s} /+$ & $\mathrm{C} / \mathrm{+}$ & $+1+$ & $\mathrm{C} / \mathrm{s}$ & $\mathrm{C} / \mathrm{C}$ & \\
\hline \multicolumn{8}{|l|}{ Group I } \\
\hline Marriage $\mathrm{S} /+\times \mathrm{C} /+^{*}$ & 4 & 5 & 4 & 1 & 9 & & 19 \\
\hline Group II & & & & & & & \\
\hline Marriage $\mathrm{C} / \mathrm{C} \times+/+$ & 2 & & 5 & & & & 5 \\
\hline \multicolumn{8}{|l|}{ Group III } \\
\hline Marriage $\mathrm{C} / \mathrm{S} \times+/+$ & 3 & 3 & 2 & & & & 5 \\
\hline \multicolumn{8}{|l|}{ Group IV } \\
\hline $\begin{array}{l}\text { A Marriage } \mathrm{C} / \mathrm{S} \times \mathrm{S} /+ \\
\text { B Marriage } \mathrm{C} / \mathrm{S} \times \mathrm{C} /+\end{array}$ & $\begin{array}{l}1 \\
1\end{array}$ & & 1 & & 1 & 1 & $\begin{array}{l}2 \\
1\end{array}$ \\
\hline
\end{tabular}

$*+$ indicates corresponding normal allele, i.e., $\mathrm{S} /+=$ sickle-cell trait; $\mathrm{C} /+=$ hemoglobin $\mathrm{C}$ trait $+/+=$ all normal hemoglobin. 
others (3). Should this relative increase in abnormal offspring reappear in larger series, further investigation (for example of the possibility of maternal effect) would be necessary.

The data from group III, marriage $\mathrm{C} / \mathrm{S} \times$ $+/+$, are important in establishing the relationship of the genes for $\mathrm{C}$ and $\mathrm{S}$ hemoglobin. This group includes five offspring of three such marriages; none of the offspring is of either parental type with respect to hemoglobin.

This evidence, while not eliminating the possibility that the genes for $\mathrm{C}$ and $\mathrm{S}$ hemoglobin are independent, is statistically in favor of allelism or close linkage. If the genes for $\mathrm{C}$ and $\mathrm{S}$ hemoglobin were actually independent, one would expect to find among five such offspring some who had inherited both abnormal genes from the affected parent, or neither gene.

Further support for the allelic nature of $S$ and $\mathrm{C}$ is derived from study of the offspring of the marriages in group IV. The only marriage, $\mathrm{C} / \mathrm{S} \times \mathrm{C} /+$, produced a child of genotype $\mathrm{C} / \mathrm{C}$; this is an observation entirely consistent with the theory that $\mathrm{C}$ and $\mathrm{S}$ are allelic or closely linked.

The observation in Family J. F., where a parent of type $\mathrm{C} / \mathrm{S}$ had a child of type $\mathrm{C} / \mathrm{S}$ is consistent with allelism since the father's genotype was $\mathrm{S} /+$. Consequently, the offspring J. F. would have inherited the gene for sickle-cell hemoglobin from the father and the gene for $\mathrm{C}$ hemoglobin from her mother. The nature of the hemoglobin of the sibling A. F. $(\mathrm{C} /+)$ was also consistent with allelism or close linkage.

While these studies provide good evidence against independence of the genes for sickle-cell and $\mathrm{C}$ hemoglobin, they do not serve to distinguish between allelism and close linkage of these genes. For the distinction between allelism and close linkage, by statistical methods, a very large series would be required. Although final proof of the allelic nature of the two genes is not available, certain data may be interpreted in the light of physiological genetics as supporting the allelic theory. If the genes for these abnormal hemoglobins were either closely linked, or on different chromosomes, then in the case of the simultaneous presence of $\mathrm{C}$ and $\mathrm{S}$ hemoglobins, each gene should be accompanied by a corresponding normal allele. If independent, the arrangement might be depicted thus :

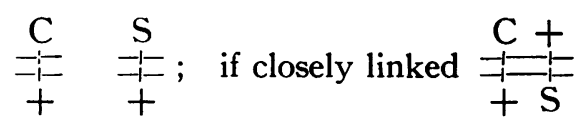

In either of these situations, the individual with genes for both $\mathrm{C}$ and $\mathrm{S}$ hemoglobins might be expected to have in addition to $C$ and $S$ hemoglobin, a significant amount of normal hemoglobin. Actually the examination in this laboratory of specimens of hemoglobin from 14 different individuals with sickle-cell-hemoglobin $\mathrm{C}$ disease has failed to reveal any hemoglobin component which could be definitely identified as normal adult hemoglobin. The majority of the specimens contained less than 5 per cent of hemoglobin migrating on filter paper faster than sickle hemoglobin; all contained less than 10 per cent of such hemoglobin. Furthermore, if filter paper electrophoresis was allowed to proceed for a longer period, this faster component of hemoglobin migrated to a position consistent with the migration of fetal hemoglobin (between sickle and normal adult hemoglobin).

The assumption could be made that the simultaneous presence of the genes for $\mathrm{C}$ and $\mathrm{S}$ hemoglobin in a single individual suppresses the formation of normal adult hemoglobin. This speculation does not find support in the study of the heterozygotes $\mathrm{S} /+$ or $\mathrm{C} /+$, where normal adult hemoglobin comprises 50 per cent or more of the total hemoglobin. These considerations add support to the hypothesis that the genes for $\mathrm{C}$ and $\mathrm{S}$ hemoglobins are alleles.

The findings in the two cases of hemoglobin $\mathrm{C}$ disease included in this report are similar to previous descriptions $(4,11,12)$ of this disorder. In both of these patients, target cells comprised 85 per cent or more of the erythrocytes; D. C. (age 52 years) had splenomegaly, while Ja. T. (age three and one-half years) did not. The presence of 15 per cent of fetal hemoglobin in patient Ja. T. whose hemoglobin level was 12 grams per cent indicates that factors other than anemia must control the synthesis of fetal hemoglobin.

\section{SUMMARY}

Observations on a total of ten families in which $\mathrm{C}$ and $\mathrm{S}$ hemoglobin occurred indicate that the genes for sickle and $\mathrm{C}$ hemoglobin segregate as simple Mendelian dominants.

Five offspring of three marriages of individuals 
with sickle-cell-hemoglobin $\mathrm{C}$ disease to individuals with normal hemoglobin were found to have either sickle-cell trait or hemoglobin $\mathrm{C}$ trait. This supports the hypothesis that the genes for C and sickle hemoglobin are alleles.

Observations on three offspring of individuals with sickle-cell-hemoglobin $\mathrm{C}$ disease and marital partners heterozygous for an abnormal hemoglobin were consistent with allelism of the genes for sickle and $C$ hemoglobin.

The fact that individuals with sickle-cell-hemoglobin $\mathrm{C}$ disease do not have any appreciable amount of normal adult hemoglobin is interpreted as evidence favoring allelism of the genes rather than linkage or independence.

Two additional cases of hemoglobin $\mathrm{C}$ disease, i.e., homozygosity for the gene for hemoglobin $\mathrm{C}$, were described.

\section{ACKNOWLEDGMENT}

The author wishes to thank Dr. Milford Fulop who referred family J. G. for study, Dr. Joseph Barlow who assisted in the family studies, and Grace Vanderhoff, B.S., for technical assistance.

The advice and assistance of Dr. Salome G. Waelsch in the preparation of the manuscript are gratefully acknowledged.

\section{REFERENCES}

1. Itano, H. A., and Neel, J. V., A new inherited abnormality of human hemoglobin. Proc. Nat. Acad. Sc., 1950, 36, 613.

2. Kaplan, E., Zuelzer, W. W., and Neel, J. V., A new inherited abnormality of hemoglobin and its in- teraction with sickle cell hemoglobin. Blood, 1951, 6, 1240.

3. Neel, J. V., Kaplan, E., and Zuelzer, W. W., Further studies on hemoglobin C. I. A description of three additional families segregating for hemoglobin C and sickle-cell-hemoglobin. Blood, 1953, 8, 724.

4. Ranney, H. M., Larson, D. L., and McCormack, G. H., Jr., Some clinical, biochemical and genetic observations on hemoglobin C. J. Clin. Invest., 1953, 32, 1277.

5. Smith, E. W., and Conley, C. L., Filter paper electrophoresis of human hemoglobins with special reference to the incidence and clinical significance of hemoglobin C. Bull. Johns Hopkins Hosp., 1953, 93, 94.

6. Kaplan, E., Zuelzer, W. W., and Neel, J. V., Further studies on hemoglobin C. II. The hematologic effects of hemoglobin $\mathrm{C}$ alone and in combination with sickle cell hemoglobin. Blood, 1953, 8, 735.

7. Larson, D. L., and Ranney, H. M., Filter paper electrophoresis of human hemoglobin. J. Clin. Invest., 1953, 32, 1070.

8. Lichtman, H. C., and Watson, R. J., Personal communication.

9. Ponder, E., and Levine, P., Fetal and adult hemoglobins in the blood of infants affected with hemolytic disease of the newborn. Blood, 1949, 4, 1264.

10. Drabkin, D. L., Spectrophotometric studies. XV. Hydration of macro sized crystals of human hemoglobin, and osmotic concentrations in red cells. J. Biol. Chem., 1950, 185, 231.

11. Spaet, T. H., Alway, R. H., and Ward, G., Homozygous type "C" hemoglobin. Pediatrics, 1953, 12, 483.

12. Watson, R. J., The hereditary anemias. Bull. New York Acad. Med., 1954, 30, 106. 